SINAI Journal of Applied Sciences (ISSN: 2314-6079) Vol. (8) Is. (2), Aug. 2019

screened BY SINAI Journal of Applied Sciences

\title{
EVALUATION AND PREDICTION OF SOME RAINFED WHEAT CULTIVARS PRODUCTIVITY UNDER NORTH SINAI REGION CONDITIONS
}

\author{
Ahmed M. Ali ${ }^{1 *}$, Eman I. El-Sarag ${ }^{2}$ and M.Y.H. Abdallah ${ }^{3}$ \\ 1. Experts Sector, Minist. Justice, Cairo, Egypt \\ 2. Dept. Plant Prod., Fac. Environ. Agric. Sci., Arish Univ., Egypt. \\ 3. Fac. Des. and Environ. Agric., Matrouh Univ., Egypt.
}

\begin{abstract}
Two open-field experiments were conducted during 2015/2016 and 2016/2017 seasons at the experimental farm, Faculty of Environ. Agric. Sciences, Arish University ( $31^{\circ} 08^{\prime} 04.3^{\prime \prime}$ $\left.\mathrm{N}, 33^{\circ} 49^{\prime} 37.2^{\prime \prime} \mathrm{E}\right)$. Egypt. This work was aimed to evaluate the performance of four bread wheat (Triticum aestivum L.) cultivars i.e.; Misr-1, Sakha-93, Giza-168 and Gemmeiza-9) in relation to different irrigation pattern i.e. surface supplemental irrigations (12 irrigations) and rainfed under the metrological conditions of North Sinai. Results obtained from the experimental field studies were used as indicators to test the performance of DSSAT-CSM (Cropping System Model) Ver. 4.5.1.023. Field experiment results indicated that under North Sinai environmental conditions, the significantly highest values of the most significant values of vegetative growth and yield and it's component were recorded by Gemmeiza- 9 cultivar under supplementary irrigation pattern, followed by rainfed Misr-1 cultivar. The output data from the CERES-Wheat model showed that Gemmeiza-9 cultivar recorded the highest observed grain yield in the $1^{\text {st }}$ and $2^{\text {nd }}$ seasons (7344 and $5928 \mathrm{~kg} \mathrm{ha}^{-1}$, respectively) and the highest predicted grain yield (3957 $\mathrm{kg} \mathrm{ha}^{-1}$ and $4619 \mathrm{~kg} \mathrm{ha}^{-1}$, respectively) as compared to other wheat cultivars Misr-1, Sakha-93 and Giza-168. Generally, Supplementary irrigated Gemmeiza-9 cultivar is recommended to maximize bread wheat grain yield under North Sinai environmental conditions and all similarity regions.
\end{abstract}

Key words: bread wheat (Triticum aestivum L.) cultivars, CERES-Wheat model, irrigation pattern, rainfed wheat, crop simulation, calibration, validation, North Sinai environmental conditions.

\section{INTRODUCTION}

Wheat (Triticum aestivum L.) is one of strategic food crops in the world and tops of cereal crops list in terms of area and production. Wheat crop can be grown under lot of different topographic and soil conditions and is adaptable to extreme weather conditions. Wheat total cultivated area in the world was about 215 million hectares during the 2017/2018 season which produced about 734.74 million tons (3. 24 ton/ha.) (USDA, 2018) thus will control the future of food security of the world, particularly under the existence of large gap among wheat production and consumption. The irrigation occurs in the arid and semi-arid regions where there is insufficient rainfall to uphold crop growth. In these areas, the inter-annual variability in irrigation application is relatively small as irrigation provides the majority of crop water requirements to sustain crop growth. Whilst such areas have tended to be the focus for most research on irrigation demand assessment, water efficiency and

\footnotetext{
* Corresponding author: Tel.: +201068064047

E-mail address: ah-ma090@yahoo.com
} 
economic evaluation (Deng et al., 2006; Prasad et al., 2006). Changes in precipitation patterns would modify the natural soil water balance. As some areas are expected to have an increase in annual precipitation levels, the intensity of blue water usage on irrigated land to compensate for any soil moisture deficiencies for optimal crop growth could thus be reduced (Gerten et al., 2011). Thus, the great challenge for the coming decades will therefore be the task of increasing food production with less water, especially in arid and semi-arid regions (Abouzeid, 1992; FAO, 2003). Water shortage and unbalanced precipitation distribution as a major problems threatening agricultural sustainability, especially winter wheat (Triticum aestivum L.) production. The proportion of water consumption from jointing to maturity averaged $56 \%$ under rain-fed conditions, but reached $64 \%$ under the optimal conditions (Wang, 2017). Grain yield and dry matter were negatively affected by water stress (Laura et al., 2008).

The Decision Support System for Agrotechnology Transfer (DSSAT) is a software application program integrating the effects of soil, crop phenotype, weather and management options that allows users to comprises crop simulation models for over 28 crops, as of Version 4.5 (DSSAT.net, 2018). CERES-Wheat model (Godwin et al., 1989; Ritchie and Otter, 1985) is a simulation model for wheat in the DSSAT package that describes daily phenological development and growth in response to environmental factors (soils, weather and management). The objectives of this study are to evaluate the performance of some wheat cultivars in relation to irrigation pattern under El-Arish-North Sinai environmental conditions. Investigation was also extended to evaluate the application of DSSAT-CERES-Wheat model for prediction of growth and yield of wheat under such conditions.

\section{MATERIALS AND METHODS}

\section{Field Experiments}

Two open field experiments were conducted at the experimental farm, Faculty of Environ. Agric. Sciences, Arish University, North Sinai $\left(31^{\circ} 08^{\prime} 04.3^{\prime \prime} \mathrm{N}\right.$, $33^{\circ} 49^{\prime} 37.2^{\prime \prime}$ E). Egypt during the two seasons of 2015/2016 and 2016/2017. This work was aimed to evaluate the performance of four bread wheat (Triticum aestivum L.) cultivars i.e.; Misr-1, Sakha93, Giza-168 and Gemmeiza-9 in relation to different irrigation pattern i.e. surface supplemental irrigations (12 irrigations) and rainfed under climatic conditions of North Sinai as a semi-arid areas. The climatic data of the field experiments, during the growing season of wheat plants in 2015/2016 and 2016/2017 were obtained from Central Laboratory for Agriculture Climate (CLAC, Egypt) and presented in Table 1.

Surface supplemental irrigations (12 Irrigations) during wheat growth period was added as recommended for semi arid region. Treatments were arranged in randomized complete block design (RCBD) in three replicates for each treatment. An area of $359 \mathrm{~m}^{2}$ was ploughed and divided to two blocks for each irrigation pattern (main plots) and wheat cultivars were arranged in the sub-plots. Row spacing was $15 \mathrm{~cm}$ apart, grains were sown by handly drilled. Fertilization and all other agricultural practices were carried out as recommended for wheat growing under the conditions of North Sinai as a semi-arid land.

\section{Recorded data}

(1) Vegetative growth; Plant height $(\mathrm{cm})$ and number of tillers/plant.

(2) Yield and its components; Spike length $(\mathrm{cm})$, spike weight $(\mathrm{g})$, spike kernel weight $(\mathrm{g})$, 1000-kernel weight $(\mathrm{g})$, number of kernel/spike, dry biological yield and grain yield $\left(\mathrm{kg} \mathrm{ha}^{-1}\right)$. 
SINAI Journal of Applied Sciences (ISSN: 2314-6079) Vol. (8) Is. (2), Aug. 2019

Table (1): Meteorological data of El-Arish, North Sinai, region during wheat growing seasons of 2015/2016 and 2016/2017.

\begin{tabular}{|c|c|c|c|c|c|c|}
\hline \multirow{2}{*}{$\begin{array}{c}\text { Period } \\
\text { Day (from-to) } / \text { Month/Year }\end{array}$} & \multicolumn{3}{|c|}{ Air Temp. $\left[{ }^{\circ} \mathrm{C}\right]$} & \multirow{2}{*}{$\begin{array}{c}\text { Av. } \\
\text { Relative } \\
\text { Humidity } \\
{[\%]}\end{array}$} & \multirow{2}{*}{$\begin{array}{c}\text { Solar } \\
\text { Radiation } \\
{\left[\mathbf{M J}-\mathbf{h r} / \mathbf{m}^{2} / \mathbf{D}\right]}\end{array}$} & \multirow{2}{*}{$\begin{array}{c}\text { Total } \\
\text { Precipitation } \\
{[\mathrm{mm}]}\end{array}$} \\
\hline & Min. & Max. & Aver. & & & \\
\hline \multicolumn{7}{|c|}{ 2015/2016 season } \\
\hline 15-30 November 2015 & 18.28 & 23.15 & 20.71 & 66.15 & 10.96 & 8.49 \\
\hline 1-15 December 2015 & 14.63 & 18.65 & 16.64 & 65.43 & 9.45 & 15.83 \\
\hline 16-31 December 2015 & 13.70 & 18.64 & 16.17 & 65.21 & 9.99 & 16.85 \\
\hline 1-15 January 2016 & 12.96 & 17.68 & 15.32 & 69.24 & 8.96 & 14.82 \\
\hline 16-31 January 2016 & 11.35 & 15.09 & 13.22 & 68.71 & 9.92 & 31.28 \\
\hline 1-15 February 2016 & 12.38 & 18.06 & 15.22 & 69.89 & 12.99 & 12.46 \\
\hline 16-29 February 2016 & 14.31 & 20.73 & 17.52 & 70.84 & 16.56 & 13.48 \\
\hline 1-15 March 2016 & 14.51 & 21.42 & 17.97 & 65.46 & 17.31 & 1.41 \\
\hline 16-31 March 2016 & 14.09 & 19.74 & 16.91 & 67.81 & 19.08 & 7.61 \\
\hline 1-15 April 2016 & 16.46 & 23.51 & 19.98 & 68.45 & 21.24 & 9.90 \\
\hline 16-30 April 2016 & 17.94 & 25.69 & 21.81 & 64.99 & 24.18 & 0.00 \\
\hline \multirow[t]{2}{*}{ 1-15 Мay 2016} & 19.23 & 26.05 & 22.64 & 62.88 & 24.61 & 0.05 \\
\hline & \multicolumn{5}{|c|}{ 2016/2017 season } & \\
\hline 15-30 November 2016 & 16.83 & 22.53 & 19.68 & 55.64 & 11.79 & 53.60 \\
\hline 1-15 December 2016 & 14.74 & 18.73 & 16.74 & 68.39 & 9.10 & 55.97 \\
\hline 16-31 December 2016 & 12.45 & 16.36 & 14.40 & 67.74 & 9.38 & 17.15 \\
\hline 1-15 January 2017 & 10.97 & 16.04 & 13.51 & 66.23 & 10.01 & 5.44 \\
\hline 16-31 January 2017 & 12.14 & 16.60 & 14.37 & 70.47 & 10.61 & 10.06 \\
\hline 1-14 February 2017 & 11.70 & 16.72 & 14.21 & 70.57 & 13.25 & 10.41 \\
\hline 15-28 February 2017 & 11.25 & 16.85 & 14.05 & 67.18 & 13.82 & 22.81 \\
\hline 1-15 March 2017 & 13.45 & 19.42 & 16.44 & 71.22 & 17.76 & 3.21 \\
\hline 16-31 March 2017 & 13.90 & 19.35 & 16.62 & 72.22 & 19.06 & 0.23 \\
\hline 1-15 April 2017 & 15.14 & 21.35 & 18.25 & 70.73 & 19.91 & 3.31 \\
\hline 16-30 April 2017 & 16.16 & 23.02 & 19.59 & 66.97 & 24.02 & 0.00 \\
\hline 1-15 Мау 2017 & 18.34 & 25.36 & 21.85 & 68.91 & 25.61 & 0.00 \\
\hline
\end{tabular}

Source: Central Laboratory for Agricultural Climate (CLAC, Egypt). 


\section{Statistical Analysis}

All data were subjected to statistical analysis for two seasons and their combined using analysis of variance technique (MSTAT-C) computer software package (Russell, 1986) with three replicates. The means values were compared at 0.05 level of probability using Duncan's Multiple Range Test of Mean Separation (Duncan, 1955).

\section{Crop modeling}

Results obtained from experimental field studies and the environmental conditions were used as a data base for calibration and validation of CERES-Wheat through DSSAT-CSM (Cropping System Model) Ver. 4.5.1.023 software to simulate and predict wheat growth and yield. The comparison between actual data (observed) and predicted data were done through CERES-Wheat model under DSSAT interface in three steps, retrieval data (converting data to CERES-Wheat model), and validation data (comparing between predicted and observed data) and run the DSSAT model provides validation of the crop models that allows users to compare simulated outcomes with observed results. Necessary files were prepared as required. Calibration and validation of applying CERES-Wheat model was done through using d-Stat index of agreement between simulated and observed values.

\section{Genetic coefficient}

DSSAT model analyzed the sensitivity of the crop biological responses to changes in the coefficients that relate to phenology. The DSSAT-CERES-Wheat Model was run with weather data and experimental data for the studied four cultivars i.e.; Misr-1, Sakha-93, Giza-168 and Gemmeiza-9 to calculate the genetic coefficient (P1V, P1D, P5, G1, G2 and PHINT) for each variety by using sub model GENCALC program, which is part of the DSSAT. The coefficients were prepared as provided by Fayed et al. (2015).

\section{Evaluation of applying DSSAT-CERES- Wheat Model}

There are different statistic indexes that comes with the model output files, including, the normalized root mean square error (RMSE) that is expressed in percent, calculated as explained by Loague and Green (1991)

RMSE gives a measure (\%) of the relative difference of simulated vs. observed data. The simulation is considered excellent with RMSE $<10 \%$, good if 10 $20 \%$, fair if $20-30 \%$, poor $>30 \%$ (Jamieson et al., 1991). For yield and yield components, the mean square error (MSE) was calculated into a systematic (MSEs) and unsystematic (MSEu) component as it is explained by Willmott (1981). The Index of Agreement $(d)$ as described by Willmott et al. (1985).

\section{RESULTS AND DISCUSSION}

\section{Field Experiments}

The interaction between irrigation pattern and wheat cultivars on growth and yield and it's components under North Sinai environmental conditions in both 2015/ 2016, 2016/2017 seasons and their combined were investigated (Tables 2-4).

\section{Vegetative characters}

Obtained results (Table 2) indicate that plant height $(\mathrm{cm})$ and number of tillers per wheat plant were significantly governed by the studied interaction either in both the two experimental seasons (2015/2016 and $2016 / 2017$ ) or the combined analysis. Gemmeiza-9 cultivar planted under supplementary irrigation achieved the tallest wheat plant. This finding was true in either $1^{\text {st }}$ and $2^{\text {nd }}$ seasons or the combined (92.23, 94.10 and $93.17 \mathrm{~cm}$, respectively). Moreover, plant height of such interacted treatment were not at par with that achieved by the same cultivar under rainfed irrigation treatment. Rainfed wheat of such potent 
SINAI Journal of Applied Sciences (ISSN: 2314-6079) Vol. (8) Is. (2), Aug. 2019

Table (2): Effect of the interaction between irrigation pattern and wheat cultivars on plant height $(\mathrm{cm})$ and no. tillers/plant of wheat plants under North Sinai environmental conditions $(2015 / 16$ and $2016 / 17$ seasons and combined analysis).

\begin{tabular}{|c|c|c|c|c|c|c|c|c|}
\hline \multirow{2}{*}{$\begin{array}{l}\text { Cultivars } \\
\text { Irri. } \\
\text { Pattern }\end{array}$} & \multicolumn{4}{|c|}{ Plant height (cm) } & \multicolumn{4}{|c|}{ No. tillers/plant } \\
\hline & Misr-1 & Sakha-93 & Giza-168 & Gem.-9 & Misr-1 & Sakha-93 & Giza-168 & Gem.-9 \\
\hline \multicolumn{9}{|c|}{ 2015/2016 Season } \\
\hline Supplemental Irri. & $89.53 \mathrm{ab}$ & $77.03 \mathrm{c}$ & 82.80 bc & $92.23 \mathrm{a}$ & $3.23 \mathrm{~b}$ & $2.79 \mathrm{~d}$ & $2.87 \mathrm{~cd}$ & $3.76 \mathrm{a}$ \\
\hline Rainfed & $78.40 \mathrm{c}$ & $67.60 \mathrm{~d}$ & $69.13 \mathrm{~d}$ & $77.93 \mathrm{c}$ & $2.90 \mathrm{~cd}$ & $2.62 \mathrm{de}$ & $2.47 \mathrm{e}$ & $3.10 \mathrm{bc}$ \\
\hline \multicolumn{9}{|c|}{ 2016/2017 Season } \\
\hline Supplemental Irri. & $91.69 a b$ & $79.59 \mathrm{c}$ & 85.02 bc & $94.10 \mathrm{a}$ & $3.33 \mathrm{~b}$ & 3.06 bed & $2.94 \mathrm{~cd}$ & $3.76 \mathrm{a}$ \\
\hline Rainfed & $81.31 \mathrm{c}$ & $69.80 \mathrm{~d}$ & $71.66 \mathrm{~d}$ & 80.57 c & $3.00 \mathrm{~cd}$ & $2.86 \mathrm{~d}$ & $2.56 \mathrm{e}$ & $3.19 \mathrm{bc}$ \\
\hline \multicolumn{9}{|c|}{ Combined } \\
\hline Supplemental Irri. & $90.61 \mathrm{ab}$ & $78.31 \mathrm{c}$ & 83.91 bc & 93.17 a & $3.28 \mathrm{~b}$ & $2.91 \mathrm{~cd}$ & $2.91 \mathrm{~cd}$ & $3.64 \mathrm{a}$ \\
\hline Rainfed & $79.86 \mathrm{c}$ & $68.70 \mathrm{~d}$ & $70.39 \mathrm{~d}$ & $79.25 \mathrm{c}$ & $2.96 \mathrm{~cd}$ & $2.74 \mathrm{de}$ & $2.51 \mathrm{e}$ & $3.11 \mathrm{bc}$ \\
\hline
\end{tabular}

Table (3): Effect of the interaction between irrigation patterns and wheat cultivars on spike kernel weight (g) and 1000-kernel weight (g) under North Sinai environmental conditions (2015/16 and 2016/17 seasons and combined analysis).

\begin{tabular}{|c|c|c|c|c|c|c|c|c|}
\hline \multirow{2}{*}{ Irri. Cultivars } & \multicolumn{4}{|c|}{ Spike kernel weight (g) } & \multicolumn{4}{|c|}{ 1000-kernel weight (g) } \\
\hline & Misr-1 & Sakha-93 & Giza-168 & Gem.-9 & Misr-1 & Sakha-93 & Giza-168 & Gem.-9 \\
\hline \multicolumn{9}{|c|}{ 2015/2016 Season } \\
\hline Supplemental Irri. & $2.73 \mathrm{ab}$ & $2.13 \mathrm{~d}$ & $2.23 \mathrm{~d}$ & $2.90 \mathrm{a}$ & 57.15 ab & $48.0 \mathrm{~b}$ & 42.89 bc & 58.75 a \\
\hline Rainfed & $2.5 \mathrm{c}$ & $1.88 \mathrm{e}$ & $1.92 \mathrm{e}$ & $2.61 \mathrm{bc}$ & $54.06 \mathrm{ab}$ & $43.3 \mathrm{bc}$ & $37.95 \mathrm{c}$ & $45.58 \mathrm{~b}$ \\
\hline \multicolumn{9}{|c|}{ 2016/2017 Season } \\
\hline Supplemental Irri. & $2.78 \mathrm{~b}$ & $2.34 \mathrm{c}$ & $2.3 \mathrm{c}$ & $3.27 \mathrm{a}$ & 54.67 bc & $50.77 \mathrm{~d}$ & 49.1 de & $61.81 \mathrm{a}$ \\
\hline Rainfed & $2.72 \mathrm{~b}$ & $1.97 \mathrm{~d}$ & $2.06 \mathrm{~d}$ & $2.9 \mathrm{~b}$ & $51.28 \mathrm{~cd}$ & $45.74 \mathrm{e}$ & $39.51 \mathrm{f}$ & 56.49 b \\
\hline \multicolumn{9}{|c|}{ Combined } \\
\hline Supplemental Irri. & $2.75 \mathrm{~b}$ & $2.23 \mathrm{c}$ & $2.27 \mathrm{c}$ & $3.06 \mathrm{a}$ & $55.28 \mathrm{~b}$ & $48.01 \mathrm{~cd}$ & $45.75 \mathrm{~d}$ & $60.34 \mathrm{a}$ \\
\hline Rainfed & $2.61 \mathrm{~b}$ & $1.95 \mathrm{~d}$ & $1.99 \mathrm{~d}$ & $2.78 \mathrm{~b}$ & 53.17 b & $45.92 \mathrm{~d}$ & $38.98 \mathrm{e}$ & 51.08 bc \\
\hline
\end{tabular}

** Means having the same letter within each factor are not significantly differed at 0.05 level, according to Duncan's multiple range test. 
Table (4): Effect of the interaction between irrigation pattern and wheat cultivars on biological yield $\left(\mathrm{kg} / \mathrm{m}^{2}\right)$ and grain yield (ton/fed.) under North Sinai environmental conditions $(2015 / 16$ and $2016 / 17$ seasons and combined analysis).

\begin{tabular}{|c|c|c|c|c|c|c|c|c|}
\hline \multirow{2}{*}{$\begin{array}{l}\text { Irri. } \\
\text { Pattern }\end{array}$} & \multicolumn{4}{|c|}{ Biological yield $\left(\mathrm{kg} \mathrm{m}^{-2}\right)$} & \multicolumn{4}{|c|}{ Grain yield (ton fed- ${ }^{1}$ ) } \\
\hline & Misr-1 & Sakha-93 & Giza-168 & Gem.-9 & Misr-1 & Sakha-93 & Giza-168 & Gem.-9 \\
\hline \multicolumn{9}{|c|}{ 2015/2016 Season } \\
\hline Supplemental Irri. & $2.99 \mathrm{a}$ & $1.95 \mathrm{bc}$ & $1.74 \mathrm{bc}$ & $3.29 \mathrm{a}$ & 2.68 & 2.83 & 2.66 & 3.06 \\
\hline Rainfed & $1.96 \mathrm{bc}$ & $1.6 \mathrm{c}$ & $1.12 \mathrm{~d}$ & $2.12 \mathrm{~b}$ & 1.9 & 1.75 & 1.63 & 2.61 \\
\hline \multicolumn{9}{|c|}{ 2016/2017 Season } \\
\hline Supplemental Irri. & $3.07 \mathrm{a}$ & $2.36 \mathrm{~b}$ & $1.61 \mathrm{c}$ & $3.45 \mathrm{a}$ & $2.54 \mathrm{a}$ & $2.02 \mathrm{~b}$ & $1.39 \mathrm{c}$ & $2.82 \mathrm{a}$ \\
\hline Rainfed & $1.99 \mathrm{bc}$ & $1.59 \mathrm{c}$ & $1.05 \mathrm{~d}$ & $2.07 \mathrm{bc}$ & $1.52 \mathrm{c}$ & $1.40 \mathrm{c}$ & $1.01 \mathrm{~d}$ & $1.99 \mathrm{~b}$ \\
\hline \multicolumn{9}{|c|}{ Combined } \\
\hline Supplemental Irri. & $3.03 \mathrm{ab}$ & $2.16 \mathrm{~b}$ & $1.68 \mathrm{c}$ & $3.37 \mathrm{a}$ & $2.61 \mathrm{~b}$ & $2.43 \mathrm{~b}$ & $2.03 \mathrm{c}$ & $2.94 \mathrm{a}$ \\
\hline Rainfed & $1.98 \mathrm{bc}$ & $1.59 \mathrm{c}$ & $1.09 \mathrm{~d}$ & $2.1 \mathrm{~b}$ & $1.71 \mathrm{c}$ & $1.58 \mathrm{~cd}$ & $1.32 \mathrm{~d}$ & $2.3 \mathrm{~b}$ \\
\hline
\end{tabular}

cultivar reduced it's height in the $1^{\text {st }}$ and $2^{\text {nd }}$ seasons and combined by $15.5,14.4$ and $14.9 \%$, respectively. However, the shortest plant height of supplementary irrigated wheat cultivars was recorded for Sakha-93 cultivar (77.03, 79.59 and $78.13 \mathrm{~cm}$, respectively). This finding was fairly true in both two experimental seasons and their combined.

Under climatical conditions of North Sinai number of tillers per wheat plant was significantly affected by the interaction between irrigation pattern and cultivars in two experimental seasons and combined analysis. The highest value of number of tillers per plant was produced from supplementary irrigated Gemmeiza-9 cultivar. However, number of tillers/plant values of such potent interaction treatment was not in the par with those obtained from the same cultivar (Gemmeiza-9) under rainfed irrigation. Similarly, the lowest values of number of tillers/plant was produced under rainfed irrigation from Giza-168 cultivar. Meanwhile, Misr-1 and
Sakha-93 cultivars was taken the same trend.

Precipitation during the vegetative stage was the dominant and beneficial factor for wheat yields while increasing maximum temperature had a negative influence. Crop yields were strongly dependent on solar radiation under normal rainfall conditions. As the effect of rainfall on soil water is relatively long-lasting, its beneficial effect in vegetative stage was higher than its effect during the reproductive stage ( $Y \mathbf{u}$ et al., 2013).

In this respect Mohammadi et al. (2012) reported that the nearly equal value of correlation and path coefficients of plant height and grain yield showed that plant height had positive and direct effect on grain yield, in both conditions and suggesting a criteria trait for improving of grain yield. Similar results were obtained by Tawfelis et al. (2006), Abd El-Aty and El-Borhamy (2007), Gafaar (2007) and Semun-Tayyar (2008). 


\section{Yield and its Components}

\section{Grains weight/spike and thousand grains weight}

Results obtained in Table 3 reveale the significant effect of interaction between irrigation pattern and wheat cultivars on grains weight per spike and wheat seed index in 2015/2016;2016/2017 seasons and their combined analysis. The highest value of kernel weight of wheat spike was achieved by supplementary irrigated Gemmeiza-9 cultivar. Also, Values of such potent interaction treatment was exceeded significantly all the other studied interaction treatments in this respect. Moreover, the lowest value of the spike kernel weight was recorded by rainfed Sakha-93 cultivar. This facts was fairly true in the two experimental seasons and their combined analysis.

Seed index (1000-kernel weight) of all the studied cultivars were progressively decreased by rainfed irrigation pattern. This trend was fairly true either in the two experimental seasons or the combined. The highest value of seed index was recorded with supplementary irrigated Gemmeiza-9 cultivar. One thousand kernel weight value of such potent interaction treatment was exceeded significantly all the other studied interaction treatments in this respect. Seed index of the studied cultivars were remarkably differed in their depression response befell by rainfed irrigation pattern. Estimated improvement in 1000-kernel weight values by adding sufficient supplementary water requirements in combined were $3.8 \%$ for Misr- $1 ; 4.4 \%$ for Sakha-93; $14.8 \%$ for Giza-168 and 15.3\% for Gemmeiza-9 as compared with rainfed irrigation pattern. Such finding clear that the highest reduction in seed index was carried out for the potent Gemmeiza-9 cultivar irrespective to its insignificant superiority than the other tested cultivars in rainfed irrigation. Slight depression value of Misr-1 indicate the high flexibility of the cultivar to irrigation pattern and it's suitability to water stress. With respect to such trait, water shortage and unbalanced precipitation distribution is a major problems threatening agricultural sustainability, especially winter wheat (Triticum aestivum L.) production. Wang (2017) pointed that the proportion of water consumption from jointing to maturity averaged $56 \%$ under rain-fed conditions, but reached $64 \%$ under the optimal conditions. Also, the main water supply during the different growth periods that was suitable for achieving high yield had a nearly constant volume. Similar results also recorded by: Semun-Tayyar (2008), Hafez et al. (2012), Mohammadi et al. (2012) and Keser et al. (2017).

\section{Biological yield $\left(\mathrm{kg} / \mathrm{m}^{2}\right)$ and grain yield (ton/fed.)}

Obtained results (Table 4) show that supplementary irrigation pattern favored vegetative growth of Gemmeiza-9 cultivar to produce the highest value of dry biological yield. This finding was fairly true in both the two experimental seasons and their combined analysis $(3.29 ; 3.45$ and $3.37 \mathrm{~kg} \mathrm{~m}^{-2}$, respectively). On the contrary, the lowest value of wheat dry biomass was recorded in each of the $1^{\text {st }} ; 2^{\text {nd }}$ seasons and combined with rainfed irrigated Giza-168 cultivar $\left(1.74 ; 1.61\right.$ and $1.68 \mathrm{~kg} \mathrm{~m}^{-2}$, respectively). Supplementary irrigation seem to be more suitable pattern for both Misr-1 and Sakha-93 cultivars either in the $1^{\text {st }}$ and $2^{\text {nd }}$ season or in combined analysis to produce the optimum vegetative growth and consequently their highest values of dry biomass comparing with rainfed irrigated cultivars. More or less, supplementary irrigated Gemmiza-9 cultivar out-yielded those of rainfed in $1^{\text {st }} ; 2^{\text {nd }}$ and combined by about $(35.6 \% ; 40.0 \%$ and $37.8 \%$, respectively). These results agree with those reported by Laura et al. (2008) who found that grain yield and dry matter were negatively affected by water stress Some of researchers indicated the positive correlation 
between grain yield and yield component traits in wheat such as biological yield (Ghaderi et al., 2009; Kandic et al., 2009), plant height (Leilah and Al-Khateeb, 2005), grains per spike (Khan et al., 2010) and 1000 kernel weight (Leilah and AlKhateeb, 2005).

Recorded results indicated that grain yield (ton/fed) was significantly governed by the studied interaction treatments either in 2016/2017 experimental seasons or in the combined analysis. Supplementary irrigated Gemmeiza-9 cultivar achieved the highest value of grain yield. This finding was true in either $2^{\text {nd }}$ season or the combined $(2.82$ and 2.94 ton/fed.). However, grain yield of such interacted treatment was at par with that yielded by the same cultivar under rainfed irrigation pattern in the $2^{\text {nd }}$ season and combined. Rainfed irrigation for such potent cultivar decreased its grain yield value in the $2^{\text {nd }}$ season and combined by 29.4 and $21.8 \%$

Misr-1 cultivar produced its highest value of grain yield under supplementary irrigation pattern in the combined analysis (2.61 ton/fed). However, Sakha-93 and Giza-168 were in the same trend of each Misr-1 and Gemmeiza-9 cultivars in the combined analysis in order to its highest grain yield in supplementary irrigation pattern (2.43 and 2.03 ton/fed). On the contrary, rainfed irrigation pattern for each of the studied cultivars ordinarily decreased the grain yield. In this connection, the lowest grain yield was provided by Giza168 cultivar ( 1.01 ton/fed) in the $2^{\text {nd }}$ season.

This trend of results may refer to the importance of adding a supplemental irrigation at tillering stage that only increased plant height and number of tillers/plant. However, the supplemental irrigation at heading stage only gave the highest grain yield and increased its components (Hussein, 2005). Variation in wheat cultivars grain yield as affected by irrigation pattern was also reported by
Mostafa et al. (2018) who revealed that the grain yield was marginally influenced by irrigation intervals under double and single line a bed. The supplemental irrigation caused the grain yield to increase significantly up to $58 \%$ (Erekul et al., 2012)

\section{Crop Model}

The CERES-Wheat model was used to quantify variability in wheat growth and grain yield over the two seasons, 2015/2016 and 2016/2017 in North Sinai (El-Arish) region conditions. The model simulated growth and grain yield of the studied four cultivars (Misr-1; Sakha-93; Giza-168 and Gemmeiza-9) and two irrigation patterns (supplementary and rainfed). Daily weather data, soil profile properties, soil profile initial conditions, irrigation management data, crop management data and genetic coefficients of wheat as described in the materials and methods. DSSAT-CERESWheat model was validated and evaluated by d-Stat between observed values of field measurements and predicted values obtained by the model.

\section{Number of days from sowing to anthesis}

Results presented in Table 5 showed the comparison between observed and predicted number of days from sowing to anthesis date in the two experimental seasons, 2015/ 2016 and 2016/2017 in North Sinai (ElArish) environmental conditions.

It will be necessary to clarify that the CERES-Wheat model calculated the number of days from sowing to anthesis using the input Agro-meteorological data on the basis of optical-clocks received by the plant and not the days recorded.

Anthesis date results indicated that the output data from the CERES-Wheat model were in harmony with the observed data in both seasons (2015/2016 and 2016/2017) of the experiment. Differences in number of days from sowing to anthesis due to irrigation pattern effect in both results of 
SINAI Journal of Applied Sciences (ISSN: 2314-6079) Vol. (8) Is. (2), Aug. 2019

Table (5): Observed and predicted number of days from sowing to anthesis four bread wheat cultivars as affected by different irrigation pattern in $2015 / 2016$ and 2016/2017 seasons

\begin{tabular}{|c|c|c|c|c|c|c|c|}
\hline \multicolumn{2}{|c|}{ Seasons } & \multicolumn{3}{|c|}{$2015 / 2016$} & \multicolumn{3}{|c|}{ 2016/2017 } \\
\hline Cultivar & Irrigation Pattern & Observed & Predicted & d-Stat* & Observed & Predicted & d-Stat* \\
\hline \multirow{2}{*}{ Misr-1 } & Supplemental Irri. & 93 & 99 & \multirow{2}{*}{0.811} & 95 & 101 & \multirow{2}{*}{0.864} \\
\hline & Rainfed & 87 & 96 & & 88 & 98 & \\
\hline \multirow{2}{*}{ Sakha-93 } & Supplemental Irri. & 92 & 100 & \multirow{2}{*}{0.807} & 94 & 102 & \multirow{2}{*}{0.853} \\
\hline & Rainfed & 88 & 97 & & 89 & 97 & \\
\hline \multirow{2}{*}{ Giza-168 } & Supplemental Irri. & 93 & 99 & \multirow{2}{*}{0.801} & 95 & 101 & \multirow{2}{*}{0.855} \\
\hline & Rainfed & 87 & 97 & & 88 & 97 & \\
\hline \multirow{2}{*}{ Gemmeiza-9 } & Supplemental Irri. & 95 & 106 & \multirow{2}{*}{0.903} & 97 & 105 & \multirow{2}{*}{0.916} \\
\hline & Rainfed & 90 & 99 & & 91 & 96 & \\
\hline
\end{tabular}

*Index of agreement (d-Stat) as described by Willmott et al. (1985)

observed and predicted data, Misr-1; Sakha-93 and Giza-168 cultivars under supplementary irrigation had earlier flowering as compared to Gemmeiza-9 cultivar. Whereas, supplementary irrigation pattern prolonged the observed and predicted number of days to anthesis for all wheat cultivars in 2015/2016 and 2016/ 2017 seasons. The CERES-wheat model predicted that Gemmeiza-9 cultivar had the longest number of days to anthesis as compared to Misr-1, Giza-168 and Sakha93 cultivars.

The d-Stat index of agreement, as absolute values, between observed and predicted number of days to anthesis for the $1^{\text {st }}$ season was from 80.1 to $90.3 \%$ and from 85.3 to $91.6 \%$ for $2^{\text {nd }}$ season.

These results may refer to the water stress effect that cause a reduction in growing cycle length of wheat for all cultivars under North Sinai (El-Arish) environmental conditions. Simulation ability of the model was similar to what obtained by Ouda et al. (2005) and Hassanein and Medany (2007). In this respect, Hassanein et al. (2012) showed that Gemmeiza-9 cultivar gave the longest observed and predicted number of days for anthesis date. Sakha-93 cultivar gave the shortest observed and predicted number of days for anthesis date.
Number of days from sowing to physiological maturity date

The comparison between observed and predicted number of days from sowing to physiological maturity date in the two experimental seasons 2015/2016 and 2016/2017 under North Sinai (El-Arish) environmental conditions is presented in Table 6.

Obtained results on the differences in number of days from sowing to physiological maturity due to irrigation pattern and cultivars in both results of observed and predicted data indicated that, Gemmeiza-9 cultivar was the latest cultivar to reach the physiological maturity as compared with Misr-1; Sakha-93 and Giza-168 cultivars under supplementary irrigation pattern for observed data averaged by $1.4 \%$ in the $1^{\text {st }}$ season. Gemmeiza-9 needed the longest observed period $(145 \mathrm{~d})$ to reach the physiological maturity stage. Likewise, the length of growing cycle was reduced by $2.8 \%$ when Sakha-93 cultivar irrigate by supplementary irrigation in the $2^{\text {nd }}$ season. However, the prevailing climatic conditions and fallen rains compelled such cultivar to reach the physiological maturity early as compared to Gemmeiza-9 cultivar for observed data in the $1^{\text {st }}$ season by $1.5 \%$. 
Ali, et al.

Table (6): Observed and predicted number of days from sowing to physiological maturity of four bread wheat cultivars as affected by different irrigation pattern in $2015 / 2016$ and $2016 / 2017$ seasons

\begin{tabular}{|c|c|c|c|c|c|c|c|}
\hline \multicolumn{2}{|c|}{ Seasons } & \multicolumn{3}{|c|}{$2015 / 2016$} & \multicolumn{3}{|c|}{$2016 / 2017$} \\
\hline Cultivar & Irrigation Pattern & Observed & Predicted & d-Stat* & Observed & Predicted & d-Stat* \\
\hline \multirow{2}{*}{ Misr-1 } & Supplemental Irri. & 142 & 149 & \multirow{2}{*}{0.812} & 144 & 149 & \multirow{2}{*}{0.78} \\
\hline & Rainfed & 130 & 137 & & 133 & 139 & \\
\hline \multirow{2}{*}{ Sakha-93 } & Supplemental Irri. & 140 & 147 & \multirow{2}{*}{0.824} & 141 & 149 & \multirow{2}{*}{0.81} \\
\hline & Rainfed & 129 & 134 & & 131 & 138 & \\
\hline \multirow{2}{*}{ Giza-168 } & Supplemental Irri. & 141 & 147 & \multirow{2}{*}{0.844} & 142 & 148 & \multirow{2}{*}{0.801} \\
\hline & Rainfed & 130 & 134 & & 132 & 136 & \\
\hline \multirow{2}{*}{ Gemmeiza-9 } & Supplemental Irri. & 143 & 149 & \multirow{2}{*}{0.891} & 145 & 150 & \multirow{2}{*}{0.86} \\
\hline & Rainfed & 131 & 136 & & 134 & 141 & \\
\hline
\end{tabular}

*Index of agreement (d-Stat) as described by Willmott et al. (1985)

These results may clarify that wheat growth cycle was more sensitive to climatic conditions and chiefly concerned by precipitation which provide shorter period for the vegetative growth and compels the wheat cultivars to complete its life cycle earlier. Simulation ability of the model was similar to what obtained by Ouda et al. (2005) and Hassanein and Medany (2007). In this respect, Hassanein et al. (2012) showed that Gemmeiza-9 cultivar gave the longest observed and predicted number of days for physiological maturity date at different irrigation regimes and Misr-1 cultivar gave the shortest observed and predicted number of days for physiological maturity date. Whereas, effects of climate factors on crop growth stages and development inter-related within specific pattern. Meteorological conditions before and after flowering will influence to wheat yield and production (Yu et al., 2013).

The d-Stat index of agreement, as absolute values, between observed and predicted number of days from sowing to physiological maturity date in 2015/2016 season was from 81.2 to $89.1 \%$ and was from 78 to $86 \%$ for $2016 / 2017$ season.

\section{Grain yield at maturity}

Table 7 shows the results of observed and predicted grain yield at maturity $\left(\mathrm{kg} \mathrm{ha}^{-1}\right)$ in the two experimental seasons $(2015 / 2016$ and 2016/2017) under North Sinai (ElArish) environmental conditions.

Regarding to the influence of irrigation patterns and the effect of varietal differences among the four wheat cultivars results indicate that the output data from the CERES-Wheat model (predicted data) was different with the observed data (Table 8). The d-Stat index of agreement, as absolute values, between observed and predicted grain yield at maturity in the $1^{\text {st }}$ season was from 78.4 to $87.9 \%$ and from 83.2 to $91.6 \%$ in the $2^{\text {nd }}$ season.

Supplementary irrigated Gemmeiza-9 cultivar recorded in the $1^{\text {st }}$ season the highest observed and predicted grain yield (7344 and $5635 \mathrm{~kg} \mathrm{ha}^{-1}$, respectively) $14.7 \%$ more than that of rainfed and exceeded other wheat cultivars Misr-1, Sakha-93 and Giza-168 in observed grain yield by $12.4,7.5$ and $13.07 \%$, respectively. Whilst, for predicted grain yield by $8.2,3.6$ and $25.9 \%$, respectively.However, the observed 
SINAI Journal of Applied Sciences (ISSN: 2314-6079) Vol. (8) Is. (2), Aug. 2019

Table (7): Observed and predicted grain yield $\left(\mathrm{kg} \mathrm{ha}^{-1}\right)$ of four bread wheat cultivars as affected by different irrigation pattern in 2015/2016 and 2016/2017 seasons.

\begin{tabular}{c|c|ccc|ccc}
\hline \multicolumn{2}{c}{ Seasons } & \multicolumn{3}{c}{ 2015/2016 } & \multicolumn{2}{c}{$2016 / 2017$} \\
\hline Cultivars & Irrigation Pattern & Observed & Predicted & d-Stat* & Observed & Predicted & d-Stat* \\
\hline \multirow{2}{*}{ Misr-1 } & Supplemental Irri. & 6432 & 5173 & 0.784 & 6096 & 5274 & 0.911 \\
& Rainfed & 4560 & 3165 & & 3648 & 3544 & \\
\hline \multirow{2}{*}{ Sakha-93 } & Supplemental Irri. & 6792 & 5430 & $\mathbf{0 . 8 2 6}$ & 4848 & 4341 & 0.832 \\
& Rainfed & 4200 & 3982 & & 3360 & 2665 & \\
\hline \multirow{2}{*}{ Giza-168 } & Supplemental Irri. & 6384 & 4178 & $\mathbf{0 . 8 6 2}$ & 3336 & 4250 & 0.856 \\
& Rainfed & 3912 & 1949 & & 2424 & 2564 & \\
\hline \multirow{2}{*}{ Gemmeiza-9 } & Supplemental Irri. & 7344 & 5635 & $\mathbf{0 . 8 7 9}$ & 6768 & 5950 & 0.916 \\
& Rainfed & 6264 & 5193 & & 4776 & 4092 & \\
\hline
\end{tabular}

*Index of agreement (d-Stat) as described by Willmott et al. (1985).

and predicted values of grain weight in the $2^{\text {nd }}$ season are on par with those obtained from the $1^{\text {st }}$ season. Supplementary irrigation showed the superiority of observed and predicted grain yield at maturity. Predictions for kernel weight were more uncertain with a slightly increasing trend in response to increasing temperatures and decreasing rainfall. (Dettori et al., 2017) Whereas, under rainfed, Gemmeiza-9 cultivar recorded also the highest observed and predicted grain yield (6768 and $5950 \mathrm{~kg}$ ha-1, respectively) $29.4 \%$ more than that of rainfed and exceeded all other wheat cultivars Misr-1 Sakha-93 and Giza-168 in observed grain yield by $9.9,28.4$ and $50.7 \%$, respectively and in predicted grain yield by 11.4, 27 and $28.6 \%$, respectively. Simulation ability of the model was similar to what obtained by Jin et al., (2018) who reported that the ratio of irrigated and rainfed wheat under no water stress was $31.55 \%$ and $17.16 \%$, respectively

It is important to note that the results of simulation study using the CERES-Wheat model under DSSAT interface are in trend with those obtained from field experiment particularly in grain yield (Table 6). Yield reduction typically occurs because water stress hastens the onset of senescence. This results in the crop not being able to capture season-ending solar radiation for biomass production, and it also shortens the timeframe for the mobilization and translocation of $\mathrm{N}$ and assimilate from plant tissues to the grain (Uauy et al., 2006; Sadras and Lawson 2013; Woo et al., 2013; Zhao et al., 2015 and Grogan et al., 2016). In this respect, Li li et al., (2018) describe the ability of the CERES-Wheat model simulation to predict wheat grain yield responses to different irrigation management methods; ranging from rainfed using historical weather data from crop easons over 33 years (1981-2014). They found that the grain and biomass yield responses to irrigation management were influenced by precipitation among years, whereby yield increased with higher precipitation.

\section{Conclusion}

Field experiment results indicated that under North Sinai environmental conditions, the most significant values of vegetative growth and yield and it's component were recorded by Gemmeiza-9 cultivar under supplementary irrigation pattern, followed by rainfed Misr-1 cultivar. The output data from the CERES-Wheat 
model showed that Gemmeiza-9 cultivar recorded the highest observed grain yield in the $1^{\text {st }}$ and $2^{\text {nd }}$ seasons (7344 and $5928 \mathrm{~kg}$ $\mathrm{ha}^{-1}$, respectively) and highest predicted grain yield (3957 kg ha' and $4619 \mathrm{~kg} \mathrm{ha}^{-1}$, respectively) as compared to other wheat cultivars Misr-1, Sakha-93 and Giza-168. So, to maximized bread wheat grain yield under Arish-North Sinai, it will necessary to recommend cultivation of Gemmeiza-9 wheat cultivar under supplementary irrigated pattern. Such recommendation will be a suitable practices to reduce yield variability as affected by increasing of potential temperature scenarios under North Sinai environmental conditions and all similarity regions.

\section{REFERENCES}

Abd El-Aty, M.S.M. and El-Borhamy, H.S. (2007). Estimates of combining ability and susceptibility index in wheat diallel crosses under drought stress and normal irrigation treatments. Egypt. J. Plant Breed., 11: 651-667.

Abouzeid, M. (1992). Study on irrigation. Water Res. Cent., Minist. Irrigation and Water Res., Cairo, Egypt.

Deng, X.P.; Shan, L.; Zhang, H. and Turner, N.C. (2006). Improving agricultural water use efficiency in arid and semiarid areas of China. Agric. Water Manage., 80: 23-40.

Dettori, M.; Cesaraccio, C. and Duce, P. (2017). Simulation of climate change impacts on production and phenology of durum wheat in Mediterranean environments using CERES-Wheat model. Field Crops Res., 206: 43-53

Duncan, D.B. (1955). Multiple Range and Multiple F. test. Biomet., (11): 1-24.

Erekul, O.; Gotz, K. and Gurbuz, T. (2012). Effect of supplemental irrigation on yield and bread-making quality of wheat (Triticum aestivum L.) varieties under the Mediterranean climatical conditions. Turkish J. Field Crops, 17 (1): 78-86.

FAO (2003). Strategy of Agricultural Development in Egypt Up To 2017. MOA. May 2003, Cairo, Egypt.

Fayed, T.B.; El-Sarag, E.I.; Hassanein, M.K. and Magdy, A. (2015). Evaluation and prediction of some wheat cultivars productivity in relation to different sowing dates under North Sinai region conditions. Ann. Agric. Sci., 60 (1): 11-20.

Gafaar, N.A. (2007). Response of some bread wheat varieties grown under different levels of planting density and nitrogen fertilizer. Minufiya J. Agric. Res., 32: 165-183.

Gerten, D.; Heinke, J.; Hoff, H.; Biemans, H.; Fader, M. and Waha, K. (2011). Global water availability and requirements for future food production. J. Hydrometeorol, 12 (5): 885-899.

Ghaderi, M.G.; Zeinalikhanghah, H.; Hosseinzadeh, A.H.; Taleei, A.R. and Naghavi, M.R. (2009). Evaluation of relationships between grain yield, yield components and the other characteristics associated with grain yield in bread wheat using multivariate statistical analysis. Iran J. Crop Res., 7 (2):573-582

Godwin, D.; Ritchie, J.; Singh, U. and Hunt, L. (1989). A user's guide to CERES Wheat-V2.10. Int. Fert. Develop. Cent. Simulation Manual IFDC-SM-2. Muscle Shoals, Alabama, 94.

Grogan, M.; Scott, C.G.; Kyle, R.A.; Zeldenrust, S.R.; Gertz, M.A.; Lin, G.; Klarich, K.W.; Miller, W.L.; Maleszewski, J.J. and Dispenzieri, A. (2016). Natural history of wild-type transthyretin cardiac amyloidosis and risk stratification using a novel staging system. J. Ame. Coll. Cardiol., 68 (10): 1014-1020. 
Hafez, E.M.; Aboukhadrah, S.H.; Gh, S.; Sorour, R. and Yousef, A.R. (2012). Comparison of agronomical and physiological nitrogen use efficiency in three cultivars of wheat as affected by different levels of $\mathrm{N}$-sources. Proc. $13^{\text {th }}$ Ed. Int. Conf. Agron., Fac. Agic., Benha Univ., Egypt, 9-10.

Hassanein, M.K. and Medany, M.A. (2007). Adapting the CERES-Wheat Model to simulate wheat under current and future climates in Egypt. Int. Conf. Climatic Changes and Their Impacts on Coastal Zones and River Deltas: Vulnerability, Mitigation, and Adaptation. April 23-25, 2007, Alex., Egypt, 66-81.

Hassanein, M.K.; Elsayed, M. and Khalil, A.A. (2012). Impacts of sowing date, cultivar, irrigation regimes and location on bread wheat production in Egypt under climate change conditions. Nat. and Sci., 10 (12): 141-150.

Hussain, S.M. (2005). Effect of supplemental irrigations, seeding rates and foliar application of potassium and macro-micro elements on wheat productivity under rainfed conditions. Bull. Fac. Agric., Cairo Univ., 454-431.

Jamieson, P.D.; Porter, J.R. and Wilson, D.R. (1991). A test of the computer simulation model ARC-WHEAT on wheat crops grown in New Zealand. Field Crops Res., 27: 337-350.

Jin, N.; Ren, W.; Tao, B.; He, L.; Ren, Q.; Li, S. and Yu, Q. (2018). Effects of water stress on water use efficiency of irrigated and rainfed wheat in the Loess Plateau, China. Sci. Total Environ., 642:1-11.

Kandic, V.; Dodig, D.; Jovic, M.; Nikolic, B. and S. Prodanovic (2009). The importance of physiological traits in wheat breeding under irrigation and drought stress. Genetika, 41(1): 11-20.
Keser, M.; Gummadov, N.; Akin, B.; Belen, S.; Mert, Z.; Taner, S.; Topal, A.; Yazar, S.; Morgounov, A.; Sharma, R.C. and Ozdemir, F. (2017). Genetic gains in wheat in Turkey: Winter wheat for dry land conditions. Crop J., 5: 533 540

Khan, A.J.; Azam, F. and Ali, A. (2010). Relationship of morphological traits and grain yield in recombination inbred with lines grown under drought conditions. Pak. J. Bot., 42 (1): 259-267.

Laura, E.; Lulli, L.; Mariotti, M.; Masoni, A. and Arduini, I. (2008). Post-anthesis dry matter and nitrogen dynamics in durum wheat as affected by nitrogen supply and soil water availability. Europ. J. Agron., 28 (2): 138-147.

Leilah, A.A. and Al-Khateeb, S.A. (2005). Statistical analysis of wheat yield under drought conditions. J. Arid. Env., 61: 483-496.

Li-li, Z.; Shu-hua, L.; Zhi-Min, W.; Pu, W.; Ying-hua, Z.; Hai-jun, Y.; Zhen, G.; Si, S.; Xiao-Gui, L.; Jia-hui, W. and Shun-li, Z. (2018). A simulation of winter wheat crop responses to irrigation management using CERES-Wheat model in the North China Plain. J. Integrative Agric., 17 (5): 1181-1193.

Loague, K. and Green, R.E. (1991). Statistical and graphical methods for evaluating solute transport models: overview and application. J. Contam. Hydrol., 7: 51-73.

Mohammadi, M.; Sharifi, P.; Karimizadeh, R. and Shefazadeh, M.K. (2012). Relationships between grain yield and yield components in bread wheat under different water availability (Dry-land and supplemental irrigation conditions). Not Bot Hort. Agrob., 40 (1):195-200.

Mostafa, H.; Reham-El-Nady, M.A. and El-Ansary, M. (2018). Drip irrigation 
management for wheat under clay soil in arid conditions. Ecol. Eng., 121: 35-43.

Ouda, S.A; El-Marsafawy, S.M.; ElKholy, M.A. and Gaballah, M.S. (2005). Simulating the effect of water stress and different sowing dates on wheat production in South Delta. J. Appl. Sci. Res., 1 (3): 268-276.

Prasad, A.; Umamahesh, N. and Viswanath, G. (2006). Optimal irrigation planning underwater scarcity. J. Irrig. Drain E., 132 (3): 228-237.

Ritchie, J. and Otter, S. (1985). Description of and performance of CERES-Wheat: A user-oriented wheat yield model. In W.O. Willis (ed). ARS Wheat Yield Project. Dept. Agric., Agric. Res. Serv. ARS-38. Washington, DC, 159-175.

Russell, D.F. (1986). MSTATC Director, Crop and Soil Sciences Department, Michigan State University, Computer Program Package Version 2.10.

Sadras, V.O. and Lawson, C. (2013). Nitrogen and water-use efficiency of Australian wheat varieties released between 1958 and 2007. Eur. J. Agron. 46: 34-41.

Semun-Tayyar (2008). Grain yield and agronomic characteristics of Romanian bread wheat varieties under the conditions of northwestern Turkey. Afr. J. Biotechnol., 7 (10): 1479-1486.

Tawfelis, M.B.; El-Sherbieny, A.A. and Abd-ElKader, M.N. (2006). Genetic studies on grain yield and some agronomic characters in some durum wheat crosses. Egypt. J. Agric. Res. 84: 1479-1492.

Uauy, C.; Brevis, J.C. and Dubcovsky, J. (2006). The high grain protein content gene Gpc-B1 accelerates senescence and has pleiotropic effects on protein content in wheat. J. Exp. Bot., 57: 2785-2794.

USDA (2018). Earth Policy Institute from U.S. Department of Agriculture Production, Supply, and Distribution, Electronic Database, at www. fas. usda. gov/psdonline

Wang, D. (2017). Water use efficiency and optimal supplemental irrigation in a high yield wheat field. Field Crops Res., 213: 213-220

Willmott, C.J. (1981). On the validation of models. Phys. Geogr., 2: 184-194.

Willmott, C.J.; Ackleson, S.G.; Davis, R.E.; Feddema, J.J.; Klink, K.M.; Legates, D.R.; O'connell, J. and Rowe, C.M. (1985). Statistics for the evaluation and comparison of models. J. Geophysical Res., 90: 8995-9005.

Woo, H.R.; Kim, H.J.; Nam, H.G. and Lim, P.O. (2013). Plant leaf senescence and death: Regulation by multiple layers of control and implications for aging in general. J. Cell Sci., 126: 4823- 4833.

Yu, Q.; Li, L.; Luo, Q.; Eamus, D.; Xu, S.; Chen, C.; Wang, E.; Liu, J. and Nielsen, D.C. (2013). Year patterns of climate impact on wheat yields. Int. J. Climatol., Wiley Online Library, DOI: 10.1002/joc.3704

Zhao, D.; Derkx, A.P.; Liu, D.C.; Buchner, P. and Hawkesford, M.J. (2015). Overexpression of a NAC transcription factor delays leaf senescence and increases grain nitrogen concentration in wheat. Plant Biol., 17: 904-913.

www. DSSAT.net ( 2018) 


$$
\begin{aligned}
& \text { الملخص العربي } \\
& \text { التقييم والتببوء بإنتاجية بعض أصناف القمح تحث ظروف الزراعة المطرية } \\
& \text { بمنطقة شمال سيناء }
\end{aligned}
$$

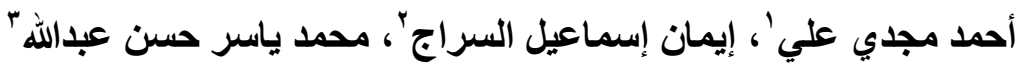

$$
\begin{aligned}
& \text { ا ـ مصلحة الخبر اه، وزارة العدل، مصر. }
\end{aligned}
$$

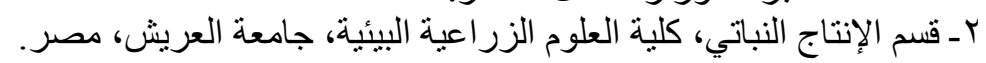

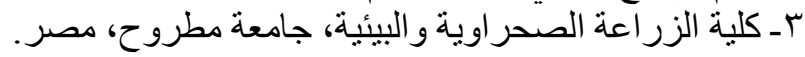

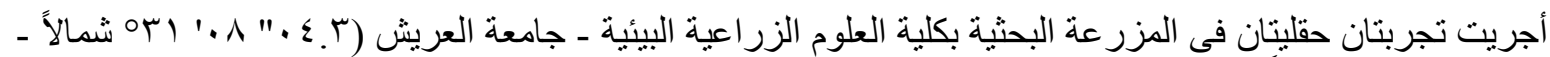

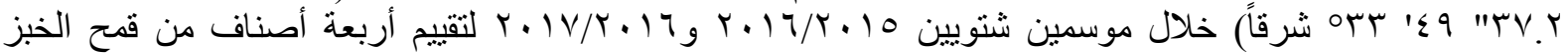

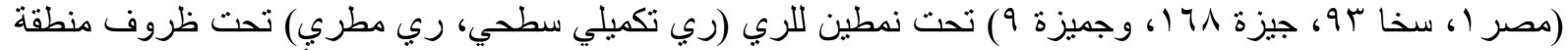

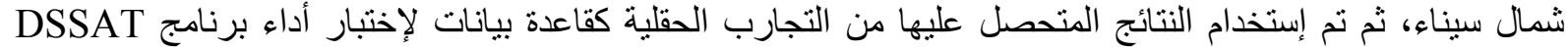

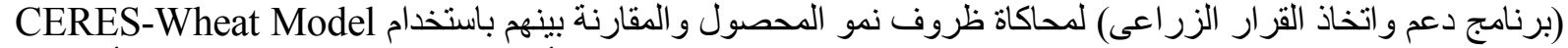

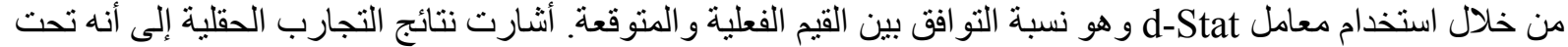

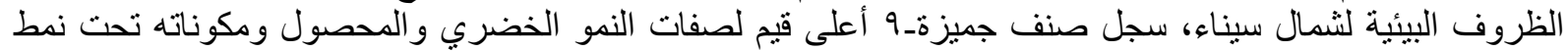

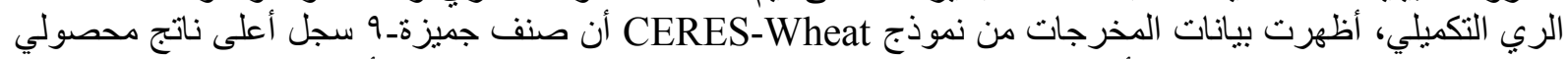

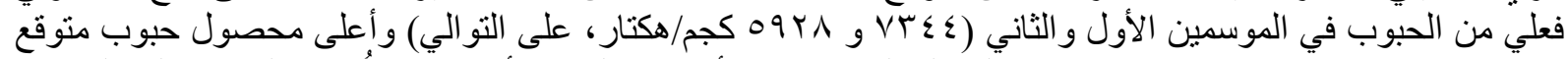

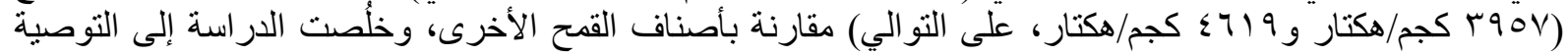

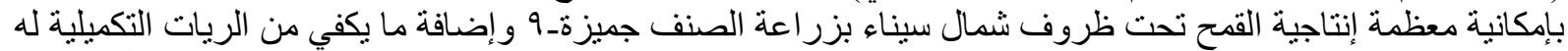

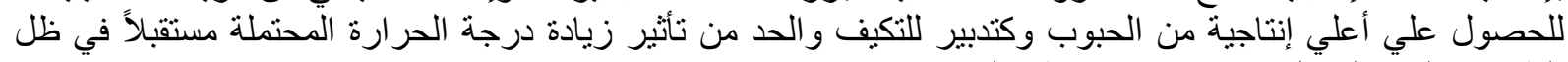
الظروف البيئية لنشمال سيناء وجميع مناطق التئه التشابه.

الكلمات الإسترشادية: أصناف قمح الخبز، أنماط الري، القمح المطري، نماذج محاكاة المحاصيل، الظروف المناخية الثمال سيناء. 
Ali, et al. 